American Journal of Anatomy and Physiology
(ISSN:2637-4714)

\title{
The vasculature of the stomach and intestinal tract during compression stenosis of the celiac axis
}

\section{Babayeva R. E.}

Azerbaijan Medical University. Department of Human Anatomy and Medical Terminology. Baku. Azerbaijan

\section{ABSTRACT}

At the current moment, there is no single approach regarding diagnostics and after-treatment of compression stenosis of the celiac axis. This work aims to study the state of the vasculature of the stomach and intestinal tract during compression stenosis of the celiac axis. Compression stenosis of the celiac axis is a disease caused by extravasal pressure of the celiac axis of the abdominal aorta applied by the arcuate ligament of the diaphragm, diaphragmatic peduncle, or neurophibromatic tissue of celiac plexus. It presents in chronic abdominal pain, dyspeptic events, and neurovegetative disorders.

This work aims to study the state of the vasculature of the stomach and intestinal tract during compression stenosis of the celiac axis.

Materials and methods. Intraorgan vasculature has been studied - 18 specimens of stomachs and intestinal tracts, gathered during autopsies of dead bodies with compression stenosis of the celiac axis. Autopsie material has been studied sensu L. Reiner. Research has been conducted with angiology, roentgenologic and histologic methods. To achieve the set goal a universal method has been developed, based on classical impregnation methods: intravascular - Ranvier-Goyer, and immersional - Belschowsky-Gros.

Results. The conducted research has allowed locating significant changes of histostructure of microcirculation vessels' vascular wall: wall shredding, edema of basal membrane, swelling of perivascular connective tissue. Overall the stomach and intestinal tract looked paralytically dilated. The most prominent morphologic changes of microvasculature have been revealed in the pyloric part of the stomach and first intestinal segment of dodecadactylon. In addition to diffuse atrophic changes of the stomach lining and intestinal lining, observed during stenosis of the celiac axis, these changes take the form of helcoid process in separate parts of it.

As a result, the conducted research has allowed exposing prominent changes of histostructure of vascular walls of stomach and intestines during compression stenosis of the celiac axis.
Keywords: Compression stenosis, occlusion, celiac axis, vasculature, stomach, intestinal tracts, histostructures, microcirculation

*Correspondence to Author:

Babayeva R. E.

Azerbaijan Medical University. Department of Human Anatomy and Medical Terminology. Baku. Azer-

baijan

How to cite this article:

Babayeva R. E.The vasculature of the stomach and intestinal tract during compression stenosis of the celiac axis .American Journal of Anatomy and Physiology, 2021, $4: 16$.

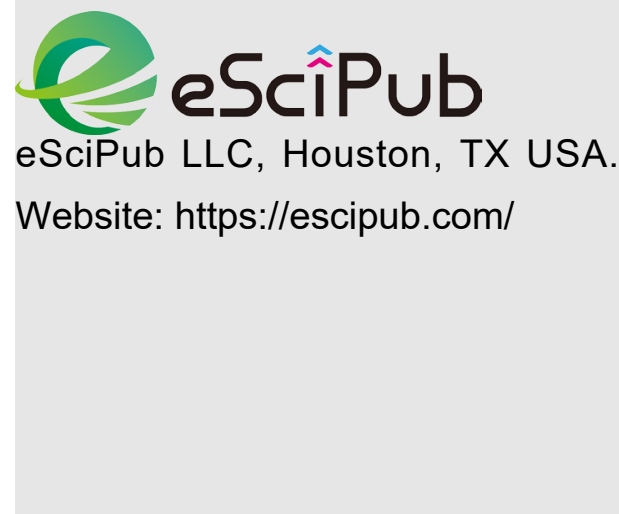




\section{INTRODUCTION}

At the current moment, there is no single approach regarding diagnostics and aftertreatment of compression stenosis of the celiac axis. This fact is to a large extent connected to a current lack of a complex system of examination of patients, who complain of chronic abdominal pains ${ }^{[1]}$. Compression stenosis of the celiac axis (celiac axis compression syndrome, Dunbar syndrome) is a disease caused by extravasal pressure of the celiac axis of the abdominal aorta applied by the arcuate ligament of the diaphragm, diaphragmatic peduncle, or neurophibromatic tissue of celiac plexus. It presents in chronic abdominal pain, dyspeptic events, and neurovegetative disorders. This is one of the key factors for the occurrence of abdominal ischemia caused by blood supply disturbance of the digestive apparatus. In some instances, it develops without symptoms. As a result of marked symptoms, it is treated surgically ${ }^{[2]}$.

In the estimation of many researchers, the formation of compression stenosis of the celiac axis is connected with peculiarities of constitution and development of aortic hiatus. Aortic hiatus is formed by tendon rims of right and left diaphragmatic peduncles, annecting medial arcuate ligament of the diaphragm and vertebral bodies. Under normal conditions, a healthy human has a medial arcuate ligament of the diaphragm situated directly above the entrance of the celiac axis. However, some people have medial arcuate ligament of diaphragm situated below the entrance of celiac axis, which leads to vessel compression and as consequence, to circulatory distress in it. Angiographic images of such patients can show how the celiac axis is pressed to the abdominal aorta, constricted near its entrance, and pathologically extended below the place of compression [3].

The anomalous layout of the medial arcuate ligament of the diaphragm is most likely a congenital pathology, as indicated by the fact that it often occurs at close relatives. In addition to that, people who suffer from compression stenosis of the celiac axis often show other developmental anomalies. That way, literature tells us that compression stenosis of the celiac axis is often connected to the asthenic constitution, mitral valve prolapse syndrome ${ }^{[4]}$, etc. Also, a connection of the disease with gastroesophageal reflux disease is observed ${ }^{[3]}$. According to L. V. Potashov and contributing authors, the celiac axis must be considered a congenital disease with an autosomal dominant type of inheritance [2].

This work aims to study the state of the vasculature of the stomach and intestinal tract during compression stenosis of the celiac axis.

\section{MATERIALS AND METHODS}

Intraorgan vasculature has been studied -18 specimens of stomachs and intestinal tracts, gathered during autopsies of dead bodies with compression stenosis of the celiac axis. Clinical histories and outpatient cards have been studied. A posthoc analysis of intestinal tract condition has been conducted, its results compared to received data.

Autopsied material has been studied sensu $\mathrm{L}$. Reiner ${ }^{[5]}$. A solution of barium sulfate has been injected through the thoracic aorta into blood channels of splanchnic apparatuses. Intestinal tracts have been ablated en bloc in combination with sources of blood supply. 21 arteries have been separated from general coeliacmesenterial circulation. Research has been conducted with angiologic, roentgeologic and histologic methods. To achieve set goal a universal method has been developed, based on classical impregnation methods: intravascular Ranvier-Goyer, and immersional Belschowsky-Gros (Марков И.И. Способ исследования микрососудистого русла большого сальника / авт.свид. № 1919100 от 08.09.1990r.) ${ }^{[6]}$.

\section{RESULTS AND DISCUSSION}

The results have shown that the most strongly pronounced changes of histostructure of microcirculation vessels' vascular wall were 
found at the submucous tissue. They were identified even in those sections of gastral and intestinal walls, where changes of microvessels of mucous lining have been absent. The thickness of the artery and arteriola walls was decreased, mainly because of the thinning of muscular layers.

Two types of occlusions of the celiac axis have been marked: concentric and eccentric. During concentric occlusion - artery opening is constricted circularly, during eccentric occlusion - at the account of thickening of lower and upper walls of it (Figure 1). Dynamics of migration of eccentric occlusions of the celiac axis into concentric have been detected neither in men nor in women.

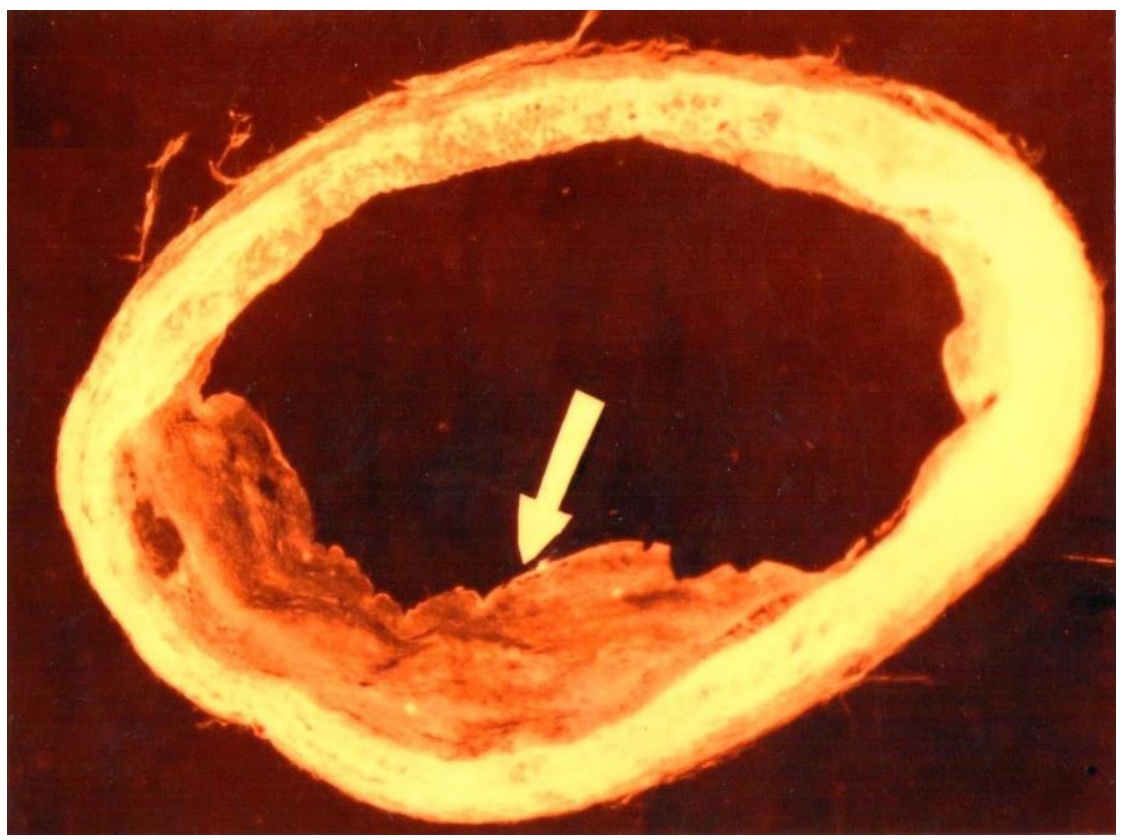

Figure 1. Eccentric occlusion. The universal method of impregnation. Magn. X1200. Photographic print from preparation.

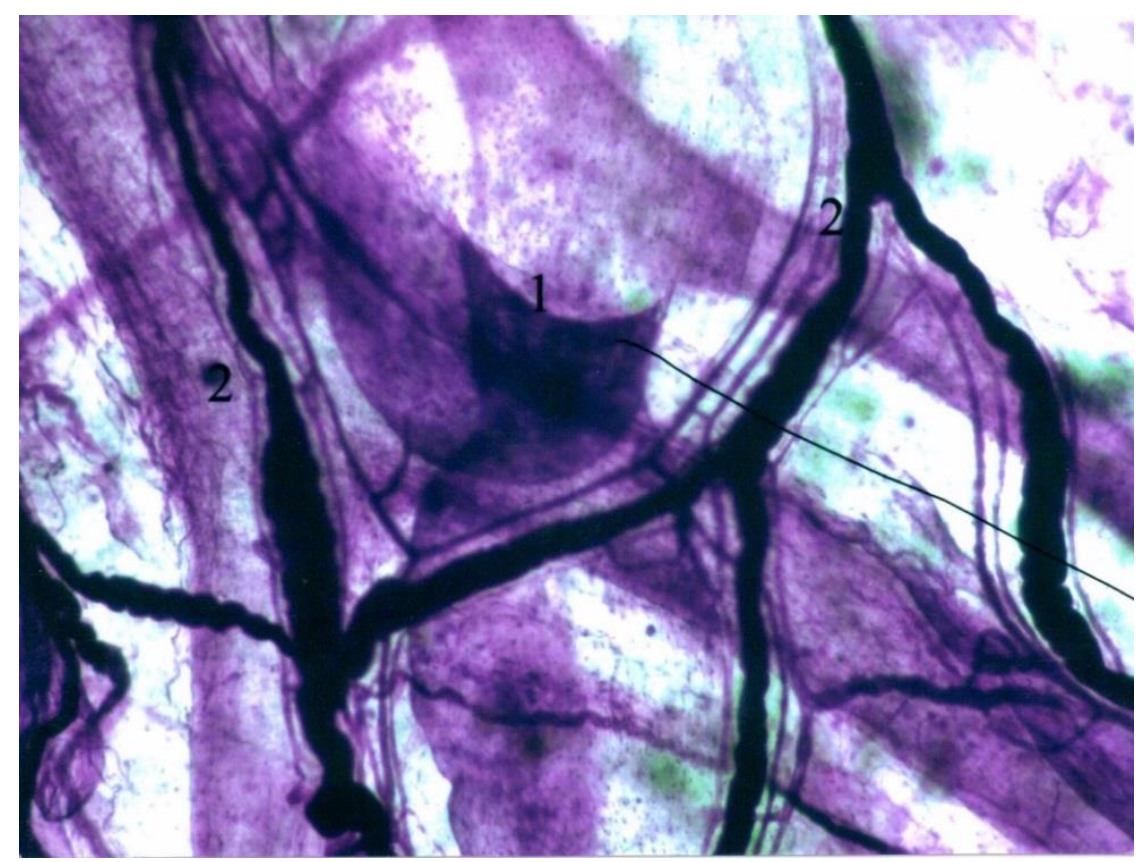

Figure 2. Microvessels in submucous tissue of bowel wall. The universal method of impregnation. Magn.900. Photographic print from preparation. 
Arterial lumen remained uniform along their entire length. Veins were nonuniformly expanded. Capillary tubes and venous capillaries had irregular deformed wall contours, nonuniform lumen, and anomalous sinuosity (Figure 2).

These microvessel changes were the most demonstrative in the pyloric part of the stomach, dodecadactylon, and terminal lleum. Expanded and deformed capillary tubes formed a dense close-meshed network here. In submucous tissue and intermuscular connective tissue, a large quantity of extra capillary blood-stream paths have been discovered. They had a significant extent, a diameter of 60-85 um. Microscopical sections showed collapsed venose sections of arteriolovenular anastomoses and veins receiving them.

The pattern of the inner surface was nonuniform, rugate. Part of the veins contained only blood plasma without formed elements. Overall the stomach and intestinal tract looked paralytically dilated. Histological studies confirmed this state: stomach and intestine preparations showed an increase of intersegmental muscle gap size, and the lumen of veins and lymphatic vessels connected to muscle segments was acutely extended. Significant changes of histostructure of microcirculation vessels' vascular wall were located: wall shredding, edema of basal membrane, swelling of perivascular connective tissue. In many cases, cross-sections of the stomach and intestinal walls showed a phenomenon of compression of nerve cords and nerve tracts at perineural space. Formation of extravasates of French-blue was observed around microvessels of submucous tissue. Defects or breakings of submucous tissue were not detected, Part of extended venous and lymphatic microvessels was closed with mural thrombi, the other part didn't contain formed elements of blood at all. The most prominent morphologic changes of microvasculature have been revealed in the pyloric part of the stomach and first intestinal segment of dodecadactylon. Strongly expanded and deformed microvessels in the stomach and dodecadactylon walls, dilated drainage venules of intestinal villi can undoubtedly be the sources of bleeding. The real danger in this context poses the dodecadactylon, which has shown the formation of hypervascular areas during evident stenosis of the celiac axis $(+3,+4)$ In addition to diffuse atrophic changes of the stomach lining and intestinal lining, observed during stenosis of the celiac axis, these changes take the form of helcoid process in separate parts of it. Microvessels were the most deformed and convoluted in the areas of ulcerations and areas adjacent to them. Their walls were thinned, destructive changed, and had many microaneurysms. During compression stenoses, the celiac axis diameter of microvessels in all sections of the stomach and intestines has significantly exceeded the diameter of similar microvessels during atherosclerotic occlusions of the abdominal aorta. The stroma of its layer of mucosal lining was infiltrated with leucocytes, lymphocytes, and plasma cells next to ulcerations. A large number of large-sized lymph nodules with reactive centers were found within it. Destructive changes were constantly observed in them, leading to the destruction of the whole lymph nodule in many cases.

The gathered data shows that the celiac axis system is most frequently afflicted with atherosclerosis. This being said, multiple atherosclerotic plaques are defined in arteries of different ranks, starting with straight arteries and ending with the entrance of the celiac axis. Our data is consistent with the studies of researchers $[7,8]$, who believe that the celiac axis is in the first place regarding atherosclerosis affliction. The entrance of the middle colic artery, owing to peculiarities of the geometry of the celiac axis, often arises dynamic stenosis even during its full permeability. This is the reason why even a slight deformation of the entrance of the middle colic artery by atherosclerotic plaque leads to its full occlusion ${ }^{[9]}$.

The triggering event for dynamic stenosis of the celiac axis is also a drastic decrease in its lumen 
after ileocolic artery discharge. This way, not so much the length of the occluded section of the artery is important, as the location of damage in critical points of arteries and shut off from the blood flow of main twigs. The most important in this regard is the middle colic artery and pancreaticoduodenal arteries. Changes in these arteries, their variability or lack make the clinical characteristics of a disease, and morphological changes in the intestinal wall clear. In the last years, an increase of myocardial infarctions has been distinguished by $1,68 \%$ of all autopsies. Notably, $71,5 \%-78 \%$ of the reasons for this were atherosclerotic changes of the celiac axis, and $2,7 \%$ of deaths of patients suffering from general atherosclerosis was due to "mesenterium arterial thrombosis" [10].

In most cases, bowel infarction has been observed in men age 61 to 70 , and women aged 71 to 80 . In the past medical history of all patients - abdominal pains resulted either a few days before bowel infarction development or they have bothered them over the course of several years ${ }^{[11]}$.

Comparison of own observations with data of clinical and morphological literature allow concluding that the most acute clinical symptoms are observed in patients with isolated stenosis of the celiac axis. They also become visible much earlier than during occlusion of the celiac artery.

According to literature data, $49 \%$ of patients with stenosis of the celiac axis had marked clinical symptoms. According to my data, from 16 cases of marked stenosis of the celiac axis, 5 cases had stomach ulcer detected, 9 cases pancreatitis or cholecystitis, 2 cases gastrointestinal hemorrhage of uncertain etiology. Liver diseases have been diagnosed during 7 autopsies. It is considered that the development of blood-flow bypath during compression stenosis happens similarly to its development during atherosclerotic occlusions. However, my data, received with autopsic material, indicates a more pronounced development of bypaths during the atherosclerotic disease of the celiac axis [12].

Thus, the diameter of pancreaticoduodenal arcades during atherosclerotic occlusions of the celiac axis was $9,1+2,8 \%$ greater than during its compression stenosis. However, it is evident that this proposition needs experimental confirmation because it is extremely difficult to pick matching materials during autopsies [12].

It is worth noting that the celiac axis has a double potential ability of blood flow recovery. This is why clinical signs of celiac axis stenosis are usually less marked and are developed over many years. System arterial pressure during occlusions of the celiac axis is elevated for most patients, while hypotension has been observed in $11,2 \%$ of cases during celiac axis stenosis ${ }^{[13]}$.

After the celiac axis decompression, the pressure returns to normal [12]. In most cases, atherosclerotic occlusions of the celiac axis have been detected during the development of its complete blocking and development of bowel infarction. In this event, total infarction has occurred, in contrast with "mosaic" necrotizing intestinal damage during non-occlusive infarctions. Studied sectioned cases of bowel infarctions and concurrently identified atherosclerotic occlusions of intestinal arteries of the middle colic artery, allows substantiating the signification of atherosclerosis in the development of non-occlusive bowel infarctions in a clinical setting.

During the general and traditional approach to the development of atherosclerotic occlusions of the celiac axis and chronic digestive organ ischemia based on them, the main attention was placed and is placed on the decrease of arterial blood flow to organs. The number of works that support the ascending nature of the atherosclerotic process in the celiac axis system - from intraorgan vessels to great vessels - is extremely negligible and have an experimental nature [2].

Section material, due to the fast development of autolytic processes, is rarely used, while biopsic 
material provides no guidance on the condition of blood-stream of the whole stomach and intestinal walls.

The study of postmortem material during the autopsy of dead bodies with occlusive diseases of the celiac axis has allowed detecting distinctive changes of intraorgan vasculature of stomach and intestines and their dynamics. The data we gathered coordinate with the results of researches that studied atherosclerotic changes of intraorgan vessels of other organs and, first of all, the heart. First of all, this is the data on the decrease of the microcirculation vessels diameter and the decrease of their number, which undoubtedly leads to deterioration of organ perfusion conditions and generates a need for the increase of perfusion pressure. There is no doubt that the prelum of blood vessels and lymphatic vessels caused by segments of the muscular layer is the one, if not the main, reason for hemorrhagic, not anemic, bowel infarction. This is why the treatment of non-occlusive bowel infarction with vasoactive drugs is ineffective. While prolonged peridural anesthesia can provide favorable results ${ }^{[3]}$.

The voiced statement is confirmed by multiple clinical observations. Thus, high arterial pressure favors the dissolution of some symptoms of digestive organs ischemic disease, while hypotension leads to bowel infarction [7].

Correlation of the data I gathered with agespecific changes in intraorganic vessels of stomach and intestines indicates their uniformity. However, the data on changes of angioarchitecture, gathered by authors during their studies of injected medications, are not confirmed by the data on histostructure restructuring in walls of microcirculatory vessels. There is no information regarding the state of extraorgan blood vessels. This is why it is impossible to differentiate the age-specific changes from atherosclerotic diseases of microcirculatory vessels at the autopsy materials with this approach. These difficulties have not been fully overcome under a complex approach to the study of blood-flow of the stomach and intestines during occlusions of the celiac axis. However, it is apparent that the changes of intraorgan blood-stream do not conform to the chronological age of patients ${ }^{[13]}$.

They emerge much earlier and are more pronounced than the changes in the corresponding age group. Morphological changes discovered in vessels of the stomach and intestines during atherosclerotic occlusion of the celiac axis outrun the chronological age of patients by $10-15$ years. This is why the outlook on the development of atherosclerotic plaques in great vessels as on compensatory process which stabilizes the bloodstream finds more supporters. The discovered atrophic changes of single and group lymph nodules are connected with the changes in their microvasculature and high sensitivity of lymphoid tissue to ischemia [14]. The topography of lymphatic follicles corresponds to areas of deficit bloodstream: free border along the intestinal tract and the area of an interfacing bloodstream. Apparently, this can be an explanation for the formation of colon ulcers and their frequent perforation in patients who are suffering typhus in the area of lymphoid nodules. Despite the difficulties of gathering reliable data while studying the gastrointestinal tract with autopsic material, it is necessary to note different qualitative changes in its intraorganic blood channel during occlusions and stenoses of the celiac axis. This way, during atherosclerotic occlusions there has been defined the decrease of diameter in microcirculatory vessels, a reduction of a part of them has been detected, the vascular penetration level decrease has been noted, thrombose and reduction of lymphatic microcirculatory vessels. Fibrinoid necrosis of walls of arterioles and arteries in the submucous layer, accompanying ischemic dissociations of bloodstream in the stomach wall, allow to presume that the formation of ulcerative lesion comes out not from the surface of mucous lining, but the submucous layer. This conception was authored by L.V.Potashov, et al. (1985). However, they believe that such a path of 
development is mandatory for all stomach ulcers and duodenal ulcers [2].

Nevertheless, the study of stomach and intestines blood channels during compressional stenoses of the celiac axis has allowed presuming that the mechanism of ulcerative lesions' development is different under this pathology. The discovered changes in it: dilation of blood capillaries, their deformation, dystonia of venal components, increase of extracapillatory bloodstreams in the submucous layer, their dystonia, and dilation, wall atrophy of arterial components of organ blood channels, vascular penetration disorder - these are the morphological measures of blood shunting in walls of stomach and intestines.

\section{CONCLUSION}

1. The conducted research has allowed locating significant changes of histostructure of microcirculation vessels' vascular wall: wall shredding, edema of basal membrane, swelling of perivascular connective tissue.

2. Overall the stomach and intestinal tract looked paralytically dilated.

3. The most prominent morphologic changes of microvasculature have been revealed in the pyloric part of the stomach and first intestinal segment of dodecadactylon.

4. In addition to diffuse atrophic changes of the stomach lining and intestinal lining, observed during stenosis of the celiac axis, these changes take the form of helcoid process in separate parts of it.

\section{ACKNOWLEDGMENTS}

The artwork and illustrations are made by the author

\section{REFRENCES}

[1]. Андреев А.В. Краснов М.В Комплексная диагностика компрессионного стеноза чревного ствола у детей. Современные проблемы науки и образования. 2018;5:12-19

[2]. Поташов Л. В., Князев М. Д., Игнашов А. М. Ишемическая болезнь органов пищеварения. 1985; 216.

[3]. Росуховский Д. А. Клинические и эходопплерографические аспекты компрессионного стеноза чревного ствола в сочетании с первичным пролапсом митрального клапана. 2009;131

[4]. Канаев А. И. Синдром компрессии чревного ствола: клиника, диагностика и лечение. 2008;39

[5]. Riener L. Mesenteric arterial incufficiency and abdominal angina. Arct. Jnt.Med., 1994;114:765-772.

[6]. Марков И.И. Импрегнация внутриорганного лимфатического русла по Ранвью. Арх.анат. 1985;6:77-79.

[7]. Новикова А.С. Клиника, ультразвуковая диагностика и хирургическое лечение компрессионного стеноза чревного ствола у детей и подростков: автореф. дис. ... канд. мед. наук. 2013;24.

[8]. Тарбаева Н. В. Синдром хронической абдоминальной ишемии, роль методов рентгеноэндоваскулярной хирургии в его лечении. 2008;125

[9]. Gümüş H., Gümüş M., Tekbaş G. et al. Clinical and multidetector computed tomography findings of patients with median arcuate ligament syndrome. Clinical Imaging. 2012;36:522-525.

[10]. Рычкова С.В., Новикова В.П. Проблема ишемической болезни органов пищеварения в детском возрасте. Лечащий врач. 2013;3:55-59.

[11]. Гавриленко А.В., Синявин Г.В. Хроническая абдоминальная ишемия: диагностика и хирургическое лечение // Регионарное кровообращение и микроциркуляция. 2012;2:4-9.

[12]. Чупин А.В., Орехов П.Ю., Лебедев Д.П., Паршин П.Ю., Лесняк В.Н., Кемеж Ю.В., Бакулина И.Ф. Этапное лечение синдрома компрессии чревного ствола (клинический случай и обзор литературы). Клиническая практика. 2013;2:26-34.

[13]. Сурнина Е.Е., Кинзерская М.Л., Дулькин Л.А., и др. Критерии оценки гемодинамической значимости аномалий и компрессионных поражений чревного ствола у детей с заболеваниями верхних отделов пищеварительного тракта. Практическая медицина. 2014;1:60-64.

[14]. Soman S., Sudhakar S.V., Keshava S.N. Celiac axis compression by median arcuate ligament on computer tomography among asymptomatic person. Indian Journal of Gastroenterology. 2010;29:121-123.

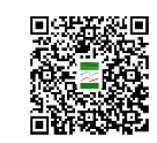

AJAP:https://escipub.com/american-journal-of-anatomy-and-physiology/ 